\title{
PHYTOPLANKTON GROWTH IN THE CONDITIONS OF MILKFISH POND CULTIVATION WITH APPLICATION OF PROBIOTICS IN EAST TEGAL DISTRICT OF TEGAL CITY, INDONESIA
}

\author{
Septiana Shinta*, Student \\ Hutabarat Johannes, Purnomo Pujiono Wahyu, Lecturers \\ Fisheries Resource Management Program, University of Diponegoro, Indonesia \\ *E-mail: shintaseptiana78@gmail.com
}

\begin{abstract}
Milkfish is one of the leading aquaculture products. Shifting the demands of aquaculture production requires a probiotic mixture on feed, although the need for phytoplankton as natural food is still very much needed. This research method is a descriptive method. This study was conducted in April-June 2018 in milkfish ponds in East Tegal District, Tegal City, Indonesia. Retrieving water samples using a bottle size of 50 liters of water which is then filtered with plankton net, then the sample is preserved with $5 \%$ formalin and immediately taken to the laboratory for identification. The purpose of this study was to: (1) determine the growth of phytoplankton during the maintenance of milkfish, and (2) analyze the relationship between nutrient availability and phytoplankton abundance. The results showed that the growth of phytoplankton was quadratic, where the highest growth was achieved on day 31 of $3,135,150$ individuals/milliliter, then decreased. The growth of functional phytoplankton is influenced by nitrate (NO3), phosphate (PO4) and total organic matter (TOM), which is indicated by the multiple regression equation $\mathrm{Y}=3779627+29580113 \mathrm{NO}_{3}-1.1 \times 10^{-8} \mathrm{PO}_{4}$ 24740.6 TOM $(\alpha<0.05)$.
\end{abstract}

\section{KEY WORDS}

Diversity, phytoplankton, milkfish ponds, East Tegal.

Milkfish is one of the most cultivated fish commodities in Indonesia. Other than having quite high protein content of $20-24 \%$ (Hafiludin, 2015), milkfish is also used as the feed for skipjack and tuna (WWF, 2014). These two reasons show that the demand for milkfish in the market is relatively high. In 2013, the production of pond fish in Central Java reached 72,350 tons, while in Tegal City it reached 939.42 tons (BPS, 2014). This production tends to increase every year.

Milkfish cultivation in the pond has been improved in term of its technology for traditional one to semi-intensive to intensive one. Semi-intensive and intensive ponds are characterized with high stocking density and administration of additional feed as well as the addition of other production infrastructure such as windmill. In Indonesia, seed stocking density for traditional/extensive technology has concentrated disperse of $6,000 \mathrm{fish} / \mathrm{ha}$, meanwhile Taiwan has 6,000 fish/ha and Philippine has 1,500 to 6,000 fish/ha (Fitz-Gerald 2004). Semi-intensive technology in Indonesia has stocking density between 8,000 to 12,000 fish/ha while Taiwan has more than 25,000 fish/ha (Mayunar et al. 2000) and The Philippines has stocking density of 12,000 fish/ha.

In general, pond in the north coast of Java is unproductive shrimp fond. Farmers put their life on the fishery that they turn to the milkfish cultivation with extensive to intensive cultivation patterns that require additional synthetic feed.

Feed cultivation administration practice can speed up the growth of the cultivation as well as influencing the increase in residual feed waste. One of the ways to overcome it is through probiotic application. According to Moriarty (1999) in Raja et al (2015), they define probiotic as the administration of living microbial creatures that give advantages to the health as well as improving the production.

Some milkfish farmers have innovated the production through the use of feed and probiotic, they have produced quite high amounted to ton/hectare/planting season within two 
months while using around two tons of feed. Based on this production scale, this quite high production is probably because of both natural and synthetic good feed management support as well as the waters quality. The availability of this natural feed can be described in the abundance and diversity of the existing plankton in the pond.

Plankton has strategic role as the natural feed for the cultivated milkfish. In its application, the growth in the food is heavily determined by the pond rehabilitation efforts through land preparation. These efforts are intended for ensuring the suitability of nutrients so that the plankton can grow well. However, the early stage of land preparation for fish cultivation often face some struggles due to imperfection of biogeochemistry process in the base of the pond and water media. As a result of this, the feasibility of the media becomes the limiting factor for the cultural graduation that can cause the death to the culture.

This research is the search for natural potential of pond land in supporting the natural stock or growth of phytopnton as well as the behavior and indications and environmental support of cultivation habitats other than from the administration of artificial feed. In the cultivation media support process, feed and probiotic residuals are expected to be the growth supporting factor of natural feed or for the milkfish cultivation. The purpose of this study was to: (1) determine the growth of phytoplankton during the maintenance of milkfish, and (2) analyze the relationship between nutrient availability and phytoplankton abundance.

\section{METHODS OF RESEARCH}

Material used in this research is phytoplankton in the form of water concentrate from the sampling results of filtering and some water volume. The supporting tools are glass-ware, microscope, Sedwick Rafter, refractometer, thermometer, spectrophotometry $\mathrm{pH}$ meter, DO meter, $\mathrm{pH}$ meter, plankton net and sample bottle.

The research method used is descriptive method namely research aims to provide or describe current condition or phenomenon by using scientific procedures to answer actual problems (Sugiyono, 2011).

This study was conducted on April-June 2018 in milkfish ponds in East Tegal District, Tegal City (Figure 1). This research is descriptive research describing the studied object.

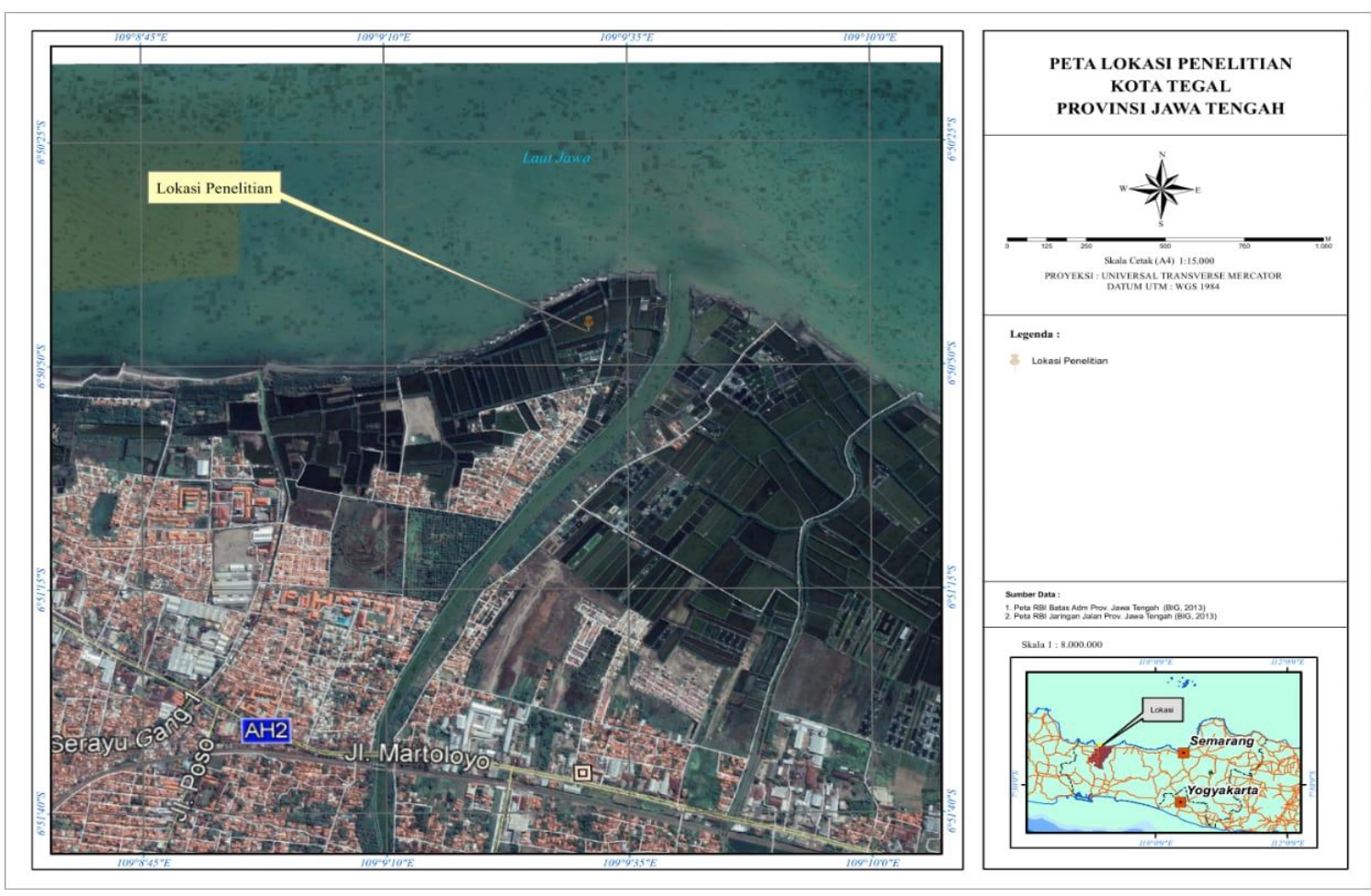

Figure 1 - Map of Research Site 
The research was conducted in the pond of $10.000 \mathrm{~m}^{2}$. Before conducting the measurement, the pond has undergone a preparatory process which includes land reversal, drying, and washing of land that takes 7 days. After filling water to the depth of $0.9 \mathrm{~m}$ which was carried out slowly for 5 days, water sampling was carried out for phytoplankton measurement and other water qualities. When the initial measurement is denoted the measurement to 0 , the measurement is continued on day $3,10,17,24,31,38,45,51,58$.

The measured variables are: phytoplankton, temperature, and salinity, $\mathrm{NO}_{3}, \mathrm{NH}_{3}, \mathrm{PO}_{4}$ and BOT. The measurement is carried out with 3 time repetitions respectively.

The observed variable measurement procedures are described below:

Retrieving water samples using a bottle size of 50 liters of water which is then filtered with plankton net, then the sample is preserved with $5 \%$ formalin and immediately taken to the laboratory for identification.

Quantitative analysis on the biology index is done to know the growth of phytoplankton including abundance, diversity, and the uniformity of Shannon-Wiener and its formulas are as follows:

$$
\mathrm{N}=\mathrm{n} \times \frac{A}{B} \times \frac{C}{D} \times \frac{1}{E}
$$

Where: $\mathrm{N}=$ Plankton abundance; $\mathrm{n}=$ number of plankton per field of view; $\mathrm{A}=$ glass cover area $\left(\mathrm{mm}^{2}\right) ; B=$ area of one field of view $\left(\mathrm{mm}^{2}\right) ; C=$ volume of filtered water $(\mathrm{ml})$; $\mathrm{D}=$ volume of one drop of water $(\mathrm{ml}) ; E=$ filtered volume (liters).

Species Diversity Index:

$$
\begin{gathered}
\mathrm{H}^{\prime}=-\Sigma \text { pi In pi } \\
\mathrm{pi}=\frac{n i}{N}
\end{gathered}
$$

Where: $\mathrm{H}^{\prime}=$ Species diversity index; $\mathrm{ni}=$ Number of individual i taxa; $\mathrm{N}=$ Total number of

\begin{tabular}{|c|c|c|c|c|c|c|c|c|c|c|c|}
\hline \multirow{2}{*}{ Class } & \multirow{2}{*}{ Genus } & \multicolumn{10}{|c|}{ Average abundance of phytoplankton (ind/l) on day: } \\
\hline & & 0 & 3 & 10 & 17 & 24 & 31 & 38 & 45 & 51 & 58 \\
\hline \multirow{6}{*}{ Chlorophyta } & Chlorella & 115000 & 451500 & 331500 & 651200 & 611000 & 635200 & 435400 & 442700 & 290300 & 399850 \\
\hline & Selenastrum & 0 & 2500 & 0 & 0 & 0 & 0 & 0 & 2500 & 0 & 0 \\
\hline & Kirchneriella & 0 & 0 & 45000 & 59250 & 25000 & 15000 & 48000 & 13500 & 7000 & 3500 \\
\hline & Oocystis & 0 & 0 & 0 & 0 & 5000 & 0 & 0 & 0 & 8100 & 4050 \\
\hline & Chlorococcum & 2500 & 0 & 0 & 0 & 12500 & 12600 & 58450 & 13500 & 16100 & 9300 \\
\hline & Desmidium & 0 & 0 & 0 & 0 & 0 & 0 & 0 & 0 & 0 & 0 \\
\hline \multirow{3}{*}{ Cyanophyta } & Anabaena & 0 & 0 & 0 & 0 & 0 & 0 & 0 & 0 & 0 & 0 \\
\hline & Chroococcus & 0 & 45000 & 159500 & 235000 & 80000 & 64250 & 275200 & 412500 & 236700 & 118350 \\
\hline & Oscillatoria & 432350 & 476750 & 577250 & 675250 & 1148750 & 729200 & 560500 & 269050 & 457150 & 412925 \\
\hline \multirow{10}{*}{ Bacillariophyta } & Amphiprora & 52500 & 57500 & 350500 & 507500 & 431250 & 700550 & 322950 & 332350 & 565350 & 389400 \\
\hline & Amphora & 0 & 1250 & 98000 & 109000 & 70000 & 69250 & 212500 & 28150 & 81750 & 40875 \\
\hline & Coscinodiscus & 0 & 110000 & 37500 & 39000 & 32500 & 14600 & 57550 & 10000 & 12000 & 6000 \\
\hline & Cymbella & 22500 & 5000 & 195000 & 137500 & 156200 & 279650 & 334650 & 293950 & 65000 & 43750 \\
\hline & Diploneis & 13500 & 0 & 67250 & 87500 & 66200 & 278760 & 127050 & 41360 & 17900 & 15700 \\
\hline & Gyrosigma & 0 & 28750 & 0 & 1500 & 0 & 17100 & 60800 & 12150 & 7000 & 3500 \\
\hline & Navicula & 0 & 2500 & 127500 & 235000 & 143000 & 157450 & 167000 & 95640 & 180500 & 90250 \\
\hline & Nitzschia & 13250 & 12500 & 236000 & 28000 & 13950 & 0 & 6000 & 19500 & 0 & 31105 \\
\hline & Cyclotella & 15000 & 16000 & 225000 & 102000 & 112150 & 141690 & 209500 & 18000 & 58450 & 36725 \\
\hline & Chaetoceros & 0 & 0 & 76250 & 12000 & 34000 & 19850 & 29150 & 0 & 26700 & 13350 \\
\hline \multicolumn{2}{|c|}{ TOTAL } & 666600 & 1209250 & 2526250 & 2879700 & 2941500 & 3135150 & 2904700 & 2004850 & 2030000 & 1618630 \\
\hline
\end{tabular}
individuals; $\mathrm{pi}=$ Proportion of $\mathrm{i}$ species.

Table 1 - Results of Phytoplankton Abundance Analysis during the study

Uniformity Index:

$$
\mathrm{E}=\frac{H^{\prime}}{H^{\prime} m a k s}
$$


Where: $E==$ Species diversity index; $H^{\prime}=$ Species diversity index; $H^{\prime}$ max = Maximum diversity index.

Measuring temperature, salinity, $\mathrm{pH}, \mathrm{DO}$ by using a thermometer, refractometer, $\mathrm{pH}$ meter and DO meter respectively. Meanwhile, the measurement of $\mathrm{NO}_{2}, \mathrm{NH}_{3}, \mathrm{PO}_{4}$ and total organic materials according to SNI number 6989.79: 2011 for testing nitrate levels, SNI number 06-6989.30-2005 for ammonia levels, SNI number 06-6989.31-2005 for phosphate levels and SNI number 06-6989.22-2004 for total organic matter levels.

Regression analysis with the help of SPSS series 23 software.is carried out in order to determine the growth of plankton, changes in water quality and their relationship.

\section{RESULTS AND DISCUSSION}

The presence of phytoplankton in milkfish ponds is closely related to the condition of the pond where nutrients come from the rest of the feed and the results of cultural metabolism. The types of phytoplankton during the study are listed in Table 1.

Based on the results of the quantity analysis of phytoplankton as presented in the table above, the growth pattern in milkfish cultivation ponds is shown in Figure 2.

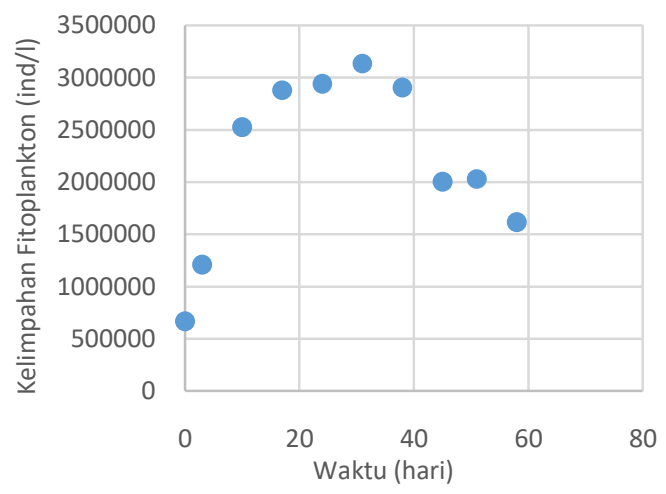

Figure 2 - Growth of Phytoplankton during Maintenance of Milkfish

Based on the measurement results of phytoplankton, the growth has two types, namely increasing from the beginning of the study to the 31st day and decreasing from the 31st day to the 58th day. The highest abundance is 3,135,159 ind/l. The initial growth equation was $Y$ $=1133405+77153.15 \times(r=0.904)(\alpha<0.05)$, while the rate of decline was $Y=4952460-$ $58605.2 \times(r=0.95)(\alpha<0.05)$.

Diversity index and phytoplankton uniformity in milkfish pond are presented in table 2.

Table 2 - Diversity and Uniformity Index of Phytoplankton in Milkfish Pond

\begin{tabular}{|c|c|c|}
\hline Time (Day) & Diversity & Uniformity \\
\hline 0 & 0.998 & 0.480 \\
\hline 3 & 1.364 & 0.531 \\
\hline 10 & 2.300 & 0.896 \\
\hline 17 & 2.094 & 0.793 \\
\hline 24 & 1.876 & 0.692 \\
\hline 31 & 2.015 & 0.763 \\
\hline 38 & 2.364 & 0.873 \\
\hline 45 & 2.013 & 0.743 \\
\hline 51 & 2.005 & 0.740 \\
\hline 58 & 1.917 & 0.691 \\
\hline
\end{tabular}

Based on the above table, it can be seen that the diversity range ranges from 1,364 to 0,998 , while the uniformity index ranges from 0,480 to 0,896 . 
Water qualities measured in this study were: temperature, $\mathrm{pH}$, salinity, $\mathrm{DO}$, nitrate, ammonia, orthophosphate and BOT. The results are presented in table 3.

Temperature variations tend to be stable on each measurement ranging from 28.00 to $33.80^{\circ} \mathrm{C}$. The degree of acidity $(\mathrm{pH})$ shows that the $\mathrm{pH}$ range is from 7.57 to 8.05 , with the lowest $\mathrm{pH}$ on day 51 and the highest on day 24.

Salinity in milkfish pond ranges from 10 to $18 \mathrm{ppt}$, where the lowest salinity is on day 3 and 10 and the highest is on day 45 and 51.

Oxygen solubility (DO) tends to be stable in the range of $2.1 \mathrm{ppm}$ to $4.73 \mathrm{ppm}$ where DO is lowest on day 3 and highest on day 51.

Table 3 - Measurement of water quality parameters

\begin{tabular}{|c|c|c|c|c|}
\hline \multirow{2}{*}{ Day of } & \multicolumn{4}{|c|}{ Water Quality Parameters } \\
\hline & Temperature & $\mathrm{pH}$ & $\mathrm{DO}$ & Salinity \\
\hline \multirow{3}{*}{0} & 32.30 & 7.70 & 4.10 & 12 \\
\hline & 31.80 & 7.69 & 3.80 & 12 \\
\hline & 32.40 & 7.70 & 4.00 & 12 \\
\hline \multirow{3}{*}{3} & 30.02 & 7.73 & 2.60 & 10 \\
\hline & 30.10 & 7.67 & 2.10 & 10 \\
\hline & 30.07 & 7.72 & 2.50 & 10 \\
\hline \multirow{3}{*}{10} & 30.02 & 7.73 & 2.50 & 10 \\
\hline & 30.10 & 7.68 & 3.80 & 10 \\
\hline & 33.80 & 7.73 & 4.20 & 10 \\
\hline \multirow{3}{*}{17} & 32.00 & 7.82 & 3.80 & 12 \\
\hline & 32.88 & 7.75 & 4.00 & 12 \\
\hline & 31.67 & 7.76 & 4.20 & 12 \\
\hline \multirow{3}{*}{24} & 28.50 & 8.05 & 3.16 & 12 \\
\hline & 28.40 & 8.01 & 4.50 & 12 \\
\hline & 29.30 & 7.70 & 4.00 & 12 \\
\hline \multirow{3}{*}{31} & 28.91 & 7.85 & 3.30 & 15 \\
\hline & 29.20 & 7.89 & 4.40 & 15 \\
\hline & 29.01 & 7.79 & 4.20 & 15 \\
\hline \multirow{3}{*}{38} & 30.01 & 7.97 & 4.46 & 16 \\
\hline & 29.71 & 7.84 & 3.40 & 16 \\
\hline & 31.80 & 7.84 & 3.30 & 16 \\
\hline \multirow{3}{*}{45} & 28.00 & 7.76 & 3.60 & 18 \\
\hline & 28.90 & 7.82 & 3.70 & 18 \\
\hline & 29.30 & 7.78 & 4.10 & 18 \\
\hline \multirow{3}{*}{51} & 33.40 & 7.72 & 4.73 & 18 \\
\hline & 32.20 & 7.60 & 3.28 & 18 \\
\hline & 32.70 & 7.57 & 3.57 & 18 \\
\hline \multirow{3}{*}{58} & 28.92 & 7.70 & 4.40 & 16 \\
\hline & 29.71 & 7.67 & 3.90 & 16 \\
\hline & 28.48 & 7.65 & 3.30 & 16 \\
\hline
\end{tabular}

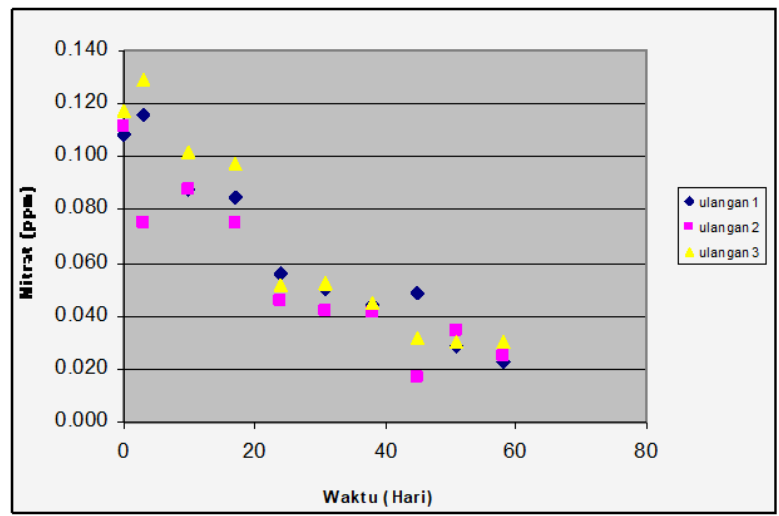

Figure 3 - State of Nitrate $\left(\mathrm{NO}_{3}\right)$ during Maintenance of Milkfish 
The nitrate content in ponds ranges from $0.03 \mathrm{ppm}$ to $0.129 \mathrm{ppm}$ and has a tendency to decrease in line with the maintenance life.

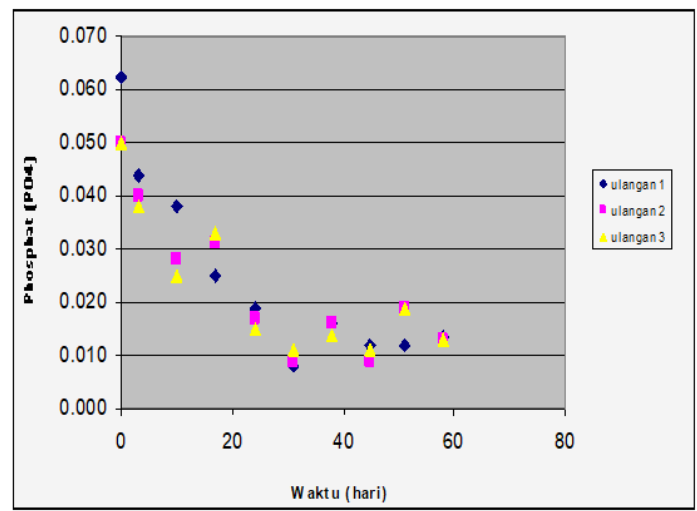

Figure 4 - State of Phosphate $\left(\mathrm{PO}_{4}\right)$ during Maintenance of Milkfish

Phosphate content in pond ranges from $0.008 \mathrm{ppm}-0.063 \mathrm{ppm}$ and the amount decreases with the maintenance life.

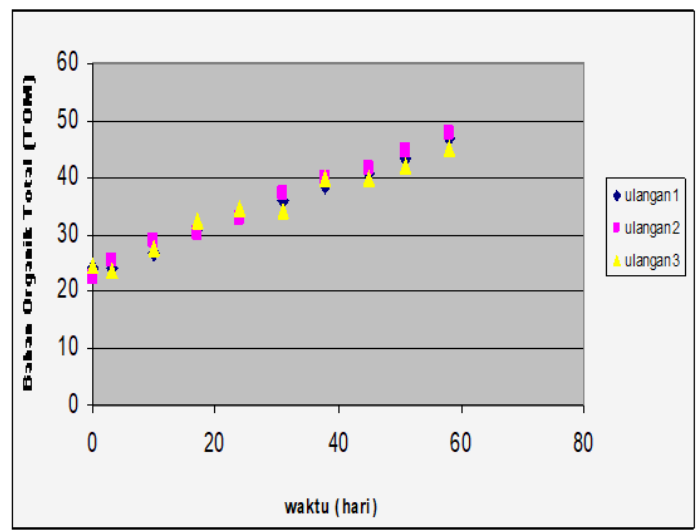

Figure 5 - The Condition of Total Organic Materials during Maintenance of Milkfish

Total Organic Material in Figure 5 shows that the total Organic Material range is from 22,385 to 47,753 and its content tends to increase with the maintenance life.

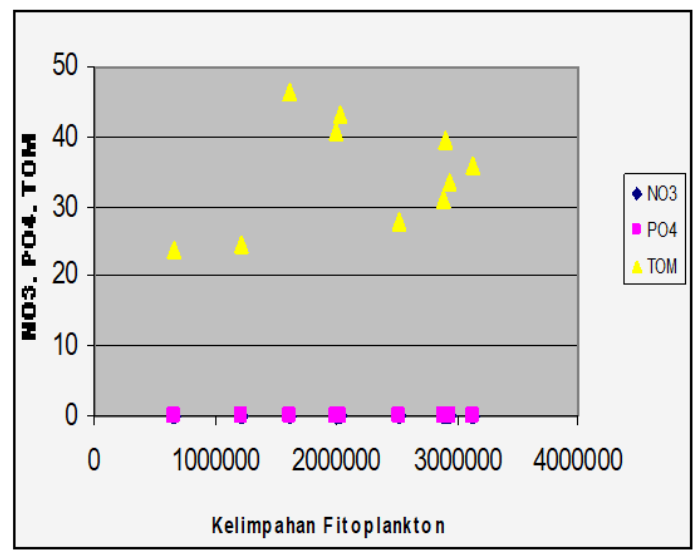

Figure 6 - Relationship between Total Nitrate, Phosphate and Organic Ingredients

The relationship between nitrate $\left(\mathrm{NO}_{3}\right)$, phosphate $\left(\mathrm{PO}_{4}\right)$ and total organic material (TOM) to plankton abundance has a very strong correlation that is $r=0.854$, while the high 
determination coefficient value is $\mathrm{R} 2=0.730$, with the equation $\mathrm{Y}=3779627+29580113$ $\mathrm{NO}_{3}-1.1 \times 10-8 \mathrm{PO}_{4}-24740.6 \mathrm{TOM}(\alpha<0,05)$. This analysis explains that phytoplankton will grow on the increasing nitrate $\left(\mathrm{NO}_{3}\right)$. The reverse pattern is shown by phosphate $\left(\mathrm{PO}_{4}\right)$ and total organic material (TOM)

\section{DISCUSSION OF RESULTS}

The number of plankton increases as the period of enlargement increases; this is related to the increase in metabolic waste and feed in the pond which as the energy source for plankton. The number of plankton increased from the beginning of the activity until the 31 st day, ranging from 666,600 - 3,135,150 individual/milliliter. According to Case et al, 2008 in Nasrullah, 2018, the increase in nutrients that enter the pond affects the composition and density of phytoplankton in the waters.

On the 31st day until the end of the study, the number of plankton began to decrease from $3,135,150$ individual/milliliter to $1,618,630$ individual/milliliter. It is probably due to the large circulation of water and the reduced amount of nutrients in the water. According to Klemeneie et al. (2007) that the main factor influencing phytoplankton community structure is a change in the condition of coastal waters including pond caused by tide and season. Reduction of phytoplankton throughout the maintenance period is also possible because of the predation process of cultivated animals in which milkfish are herbivore fish that need natural feed in addition to artificial feed in the growing process. According to Triyanto et al, 2014 , the main feed of milkfish consisting of phytoplankton (35.2-56.42\%) and zooplankton (12.22-42.8\%).

Diversity index analysis is used to determine the diversity of species of aquatic organisms. Diversity index ranged from 1,364 - 2,364 indicating that the condition of the waters is moderate. According to Michael, 1994 the value of the diversity index $\left(\mathrm{H}^{\prime}\right): 1.0$ $<H^{\prime}<3.0$ is moderate diversity which means that pond water quality is relatively good to support the development of the plankton community. High species diversity values are usually used as the clue for a comfortable and stable environment. Meanwhile, low values indicate a volatile environment (Nyabakken, 1992 in Khaerunnisa, 2015).

The uniformity index value in this study ranges from $0.480-0.896$ where the uniformity value is low to high. The high uniformity index indicates that the individual spread of each type is relatively uneven. According to Ali (1994), if the value of $E>0.75$ then the value of uniformity is high or good, whereas if the value of $E<0.75$ then the value of uniformity is low.

Water quality in the waters will affect the quality of life of the biota in it. Good water quality can support the growth, development and survival of fish. Thus, the management of water quality must be considered. One of the indications of the water quality is plankton.

The measured water quality parameters are $\mathrm{DO}, \mathrm{pH}$, temperature and salinity. Every living thing has a different tolerance limit to the environment. The limits of tolerance of living organisms to $\mathrm{pH}$ vary. They are influenced by, among others, temperature, dissolved oxygen, alkalinity, type of organism and place of life (Astuty, 2002).

Dissolved oxygen (DO) shows the amount of dissolved oxygen contained in water expressed in $\mathrm{mg} / \mathrm{L}$. Oxygen in the waters comes from photosynthesis from phytoplankton or other types of aquatic plants as well as through the process of diffusion from the air (APHA, 2005). The DO content in this study ranged from $2.1 \mathrm{mg} / \mathrm{L}-4.73 \mathrm{mg} / \mathrm{L}$. DO level fluctuates daily and seasonally depending on mixing and movement (turbulence) of water masses, photosynthetic activity, respiration and waste (effluent) that enters the body of water. In addition, higher temperature and salinity decreases oxygen solubility. Thus, oxygen level at sea tends to be lower than oxygen level in freshwater (Niklitschek \& Secor, 2009).

The $\mathrm{pH}$ value is the result of measuring the activity of hydrogen ions in water and showing a balance between acid and alkaline water. Carbonate, hydroxide, and bicarbonate will increase the alkalinity of water. Meanwhile, the presence of free mineral acids and bicarbonate acid increases acidity (Furtado et al, 2011). During the study the pond $\mathrm{pH}$ range was $7.57-8.05$ where this range is still within the normal range for aquaculture activities as well as the life of plankton. Biological activities such as photosynthesis and respiration of 
organisms, and the presence of ions in the waters affect the pH value. Xu et al. (2010) stated that waters with a $\mathrm{pH}$ between 6-9 are waters with high fertility and are classified as productive because they can encourage the process of demolition of organic matter in waters into minerals that can be utilized by phytoplankton for growth.

Milkfish is euryhaline with a wide salinity tolerance range of $0-157$ ppt. The proper salinity for milkfish growth is 5-35 ppt (SNI 5005: 2014). Measured salinity ranges from 10-18 ppt where the salinity is suitable for milkfish cultivation. According to Peter (1979) in Widiyanti (2017), salinity is one of the physical factors that can affect the rate of growth of biota and its feed consumption.

The average temperature of pond samples observed was $28.00-33.8{ }^{\circ} \mathrm{C}$ which is still in the optimum temperature range for phytoplankton growth. Astuty (2002) and Isdarmawan (2005) stated that the temperature range to support the growth of phytoplankton ranged from $20-30{ }^{\circ} \mathrm{C}$, while Crossetti \& Bicudo, 2005 stated that Chlorophyceae and diatoms would grow well in a range of temperatures of $30-35^{\circ} \mathrm{C}$ and $20-30^{\circ} \mathrm{C}$. Rianto (2008) added that temperature directly influences the rate of various metabolic processes in microalgae cells. The rate of metabolic processes will increase with increasing temperature. The optimum rate of metabolic processes can be achieved at a temperature range of $24-31^{\circ} \mathrm{C}$ (Darmono, 2001).

The nitrate content in ponds ranges from $0.03 \mathrm{ppm}$ to $0.129 \mathrm{ppm}$ and has a tendency to decrease in line with the maintenance life. The range of each value is still feasible as a medium for pond culture. According to Effendi (2003), nitrogen nitrate content of more than $0.2 \mathrm{mg} / \mathrm{L}$ can result in eutrophication of waters.

Phosphate content in pond ranges from $0.008 \mathrm{ppm}-0.063 \mathrm{ppm}$ and the amount decreases with the maintenance life. Phosphate content in natural waters ranges from 0.005 to $0.020 \mathrm{mg} / \mathrm{L}$, although the phosphate range value is higher than the content of the phosphate range in natural waters but still below the threshold of SNI 8005: 2014 which is less than $10 \mathrm{ppm}$

The accumulation of organic matter or Total Organic Matter (TOM) is probably due to the low dissolved oxygen and decomposing bacteria in the waters. The increase in the content of organic matter is caused by the remaining feeding and excretion from the organism in line with the increasing maintenance period. The research results in the field of the range of total organic ingredients were 22,385 - 47,753 mg/liter. According to Reid (1961), waters with a total organic matter content above $26.0 \mathrm{mg} / \mathrm{L}$ are classified as fertile. However, it should have not exceeded the standard quality threshold set by the State Minister of Population and Environment Decree Number 2 of 1988 concerning Quality Standards Wastewater, which is equal to $80 \mathrm{mg} / \mathrm{L}$. The variation in the content of total organic ingredients can affect the diversity of phytoplankton.

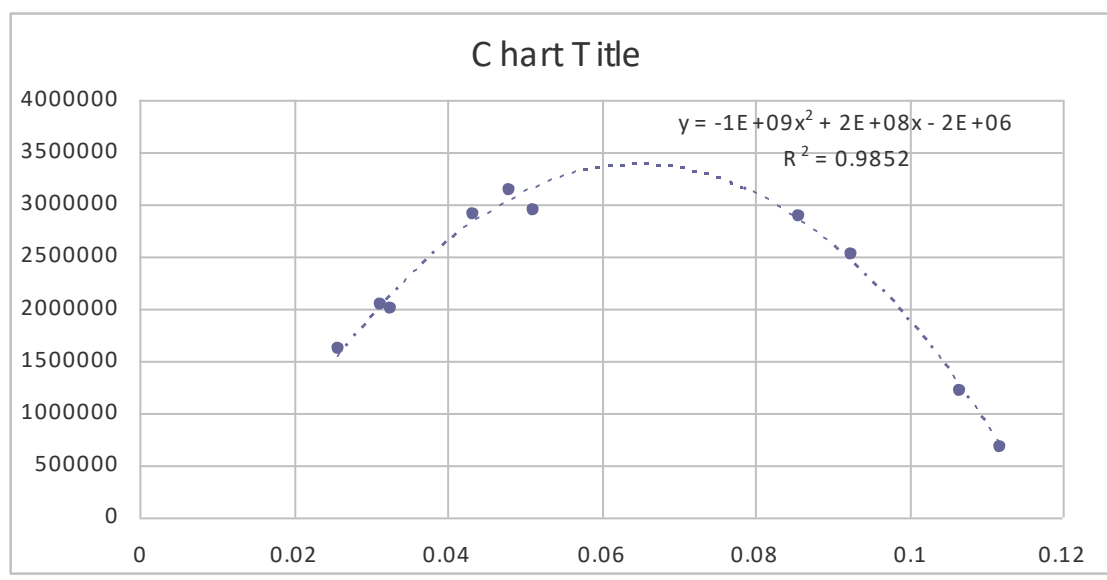

Figure 7 - Multiple regression of the effect of nitrate on phytoplankton abundance 
The relationship between nitrate, phosphate and total organic material to plankton abundance has a very strong correlation, namely $r=0.854$, while the high coefficient of determination indicates that the availability of organic matter is proportional to the growth of phytoplankton, $\mathrm{R} 2=0.730$. The multiple regression equation of the relationship is $\mathrm{Y}=3779627+29580113 \mathrm{NO}-1.1 \times 10-8 \mathrm{PO} 4-24740.6 \mathrm{TOM}(\alpha<0.05)$ with a value of $\mathrm{F}=0.0384$. The results of multiple regression equations show that nitrate, phosphate and total organic materials together have a significant effect as indicated by an $F$ value of less than 0.05 for the abundance of phytoplankton. Nitrates, phosphates and total organic matter as nutrient elements play an important role in the level of water fertility. A pond waters are said to be fertile if there are many primary producers, namely phytoplankton, both in quantity and quality as a source of natural food and also act as producers of oxygen through photosynthesis (Setyobudiandi et al, 2009).

Multiple regression equations also show that phosphate partially has a positive effect on plankton abundance whereas nitrate partially does not significantly influence. The effect of nitrate is shown in figure 7.

The amount of nitrate in pond waters is quadratic with the equation: $Y=-109 x 2+2.108 x-2.106$, where as much as 0.07 nitrate content shows the maximum value of the number of phytoplankton in the pond.

The nutrient content decreased in the middle of the maintenance period does not indicate that nutrient elements are reduced in the water. However, it indicates the process of phytoplankton predation by cultivated animals. In line with the increasing period of maintenance, milkfish requires more food and phytoplankton is a food that is usually eaten by milkfish in its natural habitat.

Milkfish are plankton-eating fish that obtain their food by filtering water from their environment using long and tight gill filters (Coad 2015).

\section{CONCLUSION}

The results of the study showed that phytoplankton growth was quadratic with the equation $Y=-109 \times 2+2.108 x-2.106$, where the highest growth was reached on day 31 of $3,135,150$ individual/milliliter, then decreased.

The growth of functional phytoplankton is influenced by nitrate $\left(\mathrm{NO}_{3}\right)$, phosphate $\left(\mathrm{PO}_{4}\right)$ and total organic material (TOM) as indicated by multiple regression equations $\mathrm{Y}=3779627+29580113 \mathrm{NO}_{3}-1.1 \times 10-8 \mathrm{PO}_{4}-24740.6$ TOM $(\alpha<0,05)$

\section{REFERENCES}

1. APHA (American Public Health Association). 2005. Standard methods for Examination of Water and Wastewater. Fourteenth Edition. APHA-AWWA-WPVC Published, American Public Health Association, 8001 Street, New York, p. 10-167.

2. Astuty, S, Iskandar, Suherman, H. 2002. Study Kualitas Air Pada Petakan Pendederan Benih Udang Windu (Panaeus Monodon Fab.) Di Kabupaten Indramayu. Universitas Padjajaran. Bandung

3. Badan Pusat Statistik Prov. Jawa Tengah and BAPPEDA Prov. Jawa Tengah. 2014. Jawa Tengan dalam Angka.

4. Basmi, H.J. 2000. Planktonologi: Plankton sebagai Bioindikator Kualitas Perairan. Fakultas Perikanan and IImu Kelautan. Institut Pertanian Bogor (IPB), Bogor.

5. Coad BW. 2015. Review of the milkfishes of Iran (Family Chanidae). Iranian Journal of Ichthyology, 2(2): 65-70.

6. Crossetti LO, Bicudo CEDM. 2005. Effects of nutrient impoverishment on phytoplankton biomass: a mesocosms experimental approach in a shallow eutrophic reservoir (Garças Pond), São Paulo, southeast Brazil. Brazilian Journal of Botany 28: 95-108.

7. Darmono. 2001. Lingkungan Hidup and Pencemaran Hubungan dengan Toksikologi Senyawa Logam. Ul. Jakarta. 
8. Djumanto, Bayu Eko Pranoto, Vinta Seta Diani \& Eko Setyobudi. 2017. Makanan and pertumbuhan ikan bandeng, Chanos chanos (Forsskål, 1775) Tebaran di Waduk Sermo, Kulon Progo.Jurnal Iktiologi Indonesia, 17(1): 83-100.

9. Efinufajri, F. 2009. Struktur Komunitas Fitoplankton Serta Keterkaitannya Dengan Perairan Di Lingkungan Tembak Udang Intensif. ITB. Bogor

10. Furtado PS, Poersch LH, Wasielesky W. 2011. Effect of calcium hydroxide, carbonate and sodium bicarbonate on water quality and zootechnical performance of shrimp Litopenaeus vannamei reared in bio-flocs technology (BFT) systems. Aquaculture 321: 130-135.

11. Hafiludin. 2015. Analisis Kandungan Gizi Pada Ikan Bandeng Yang Berasal Dari Habitat Yang Berbeda. Jurnal Kelautan Volume 8, No. 1, April 2015. ISSN: 1907-993137

12. Isdarmawan, N. 2005. Kajian tentang Pengaturan Luas and Waktu bagi Degradasi Limbah Tambak dalam Upaya Pengembangan Tambak Berwawasan Lingkungan di Kecamatan Wonokerto Kabupaten Pekalongan. Universitas Diponegoro. Semarang

13. Juanda, M, Hasrah, Yusminah Hala. 2012. Identifikasi Genus Fitoplankton pada Salah Satu Tambak Udang di Desa Bontomate'ne Kecamatan Segeri Kabupaten Pangkep. Universitas Negeri Makassar. Makassar

14. KepMen-LH No. 2. 1988. Baku Mutu Air Limbah. Kementerian Lingkungan Hidup Republik Indonesia. Jakarta

15. Koesbiono. 1981. Biologi Laut. Bogor: Fakultas. Perikanan, Institut Pertanian Bogor.

16. Mallawa, A,R.Syam, N.Naamin, S. Nurhakim, E.S.Kartamihardja, A. Poernomo, and Rachmansyah (eds.). Prosiding Simposium Perikanan Indonesia II. Ujung Pandang 2-3 Desember 1997. Hal. 136-141.

17. Nasrullah Bai Arifin, Muhammad Fakhri, Ating Yuniarti, \& Anik Martinah Hariati. 2018. Komunitas Fitoplankton Pada Sistem Budidaya Intensif Udang Vaname, Litopenaeus vannamei di Probolinggo, Jawa Timur. Jurnal ilmiah perikanan and kelautan. Volume 10.no.1. April 2018.

18. Niklitschek E.J, 2009. Dissolved oxygen, temperature and salinity effects on the ecophysiology and survival of juvenile Atlantic sturgeon in estuarine waters: II. Model development and testing. J. of Experimental Marine Biology and Ecology 381: 161-172.

19. Rahmadi Aziz, Kukuh Nirmala, Ridwan Affandi, \& Triheru Prihadi. 2015. Kelimpahan plankton penyebab bau lumpur pada budidaya ikan bandeng menggunakan pupuk N:P berbeda. Jurnal Akuakultur Indonesia 14 (1), 58-68 (2015).

20. Reid, G.K. 1961. Ecology Inland Water Estuaria. New York: Reinhold Published Co.

21. Rianto, R, Ariyani, A, Widyawan, A, Hendrayanti, D, Wardhana, W, Prihantini, B.W. 2008. Biodiversitas Cyanobacteria Dari Beberapa Situ/Danau Di Kawasan Jakarta-DepokBogor, Indonesia. Departemen Biologi, Fakultas Matematika and IImu Pengetahuan Alam, Universitas Indonesia. Indonesia

22. Budiardi. 2007. Hubungan Komunitas Fitoplankton dengan Produktivitas Udang Vanamae (Litopenaeus vannamei) di Tambak Biocrete. J. Akuak. Ind., 6(2): 119-125.

23. Terry, A.P.P, 2015. Identifikasi Fitoplankton di Perairan yang Tercemar Lumpur Lapindo, Porong Sidoarjo. Bioedukasi. 2015. Vol 8.48-51

24. Triyanto, M. Mukhlis Kamal, and Niken TM. Pratiwi. 2014. Pemanfaatan Makanan and Pertumbuhan Ikan Bandeng (Chanos chanos) Yang Diintroduksi Di Waduk IR.H. Djuanda, Jawa Barat. LIMNOTEK 201421 (1); 64-73

25. Utojo, 2014. Keragaman Plankton and Kondisi Perairan Tambak Intensif and Tradisional di Probolinggo Jawa Timur. Jurnal Akuakultur Indonesia 14 (1), 58-68 (2015)

26. Utojo. 2015. Keragaman Plankton and Kondisi Perairan Tambak Intensif and Tradisional di Probolinggo Jawa Timur. Biosfera. Volume 32 (2) Mei 2015

27. Utojo, 2016. Struktur Komunitas Plankton pada Tambak Intensif and Tradisional di Kabupaten Probolinggo, Jawa Timur. Jurnal Ilmu and Teknologi Kelautan Tropis. 8(1).

28. $\mathrm{Xu} \mathrm{H}, 2010$. Nitrogen and phosphorus inputs control phytoplankton growth in eutrophic Lake Taihu, China. Limnology and Oceanography 55: 420-432.

29. Widiyanti, A. 2017. Analisis Kualitas Air Tambak Desa Kalanganyar Kecamatan Sedati Kabupaten Sidoarjo. Journal of Research and Technology, Vol. 3 No. 1 Juni 2017. 